\title{
2 Vegetative value: promissory horizons of therapeutic \\ 3 innovation in the global circulation of ayahuasca
}

\author{
4 Emilia Sanabria ${ }^{1}$ (I)
}

\begin{abstract}
Ayahuasca is a herbal brew that is widespread in indigenous Upper Amazon and has undergone global expansion in the last decade. As it is taken up in an ever-growing range of ritual or experimental practices questions of authority, authenticity, propriety or safety become acute. This case allows us to interrogate contemporary processes of value-making as radically different and highly stratified values encounter each other, on the brink of a possible pharmaceuticalization of ayahuasca. I argue that ayahuasca is not fully captured by the value logics of capital and examine the ways in which its promissory dimensions, global circulation and entry into practices of biomedical evidence-making position it in an ambiguous space that is nevertheless not entirely outside the logics of capital. The circuits of ayahuasca's valorization reveal a complex coproduction of value that makes strategic use of various scales, sites and situations. The article examines the promissory horizon of extra-pharmacological value identified as key to understanding the efficacy of psychedelic substances such as ayahuasca. It then attends to the extraction of value from plants before closing with a reflexion on the politics of inclusion in the discussions that frame ayahuasca's value globally.
\end{abstract}

Keywords Ayahuasca $\cdot$ Value $\cdot$ Brazil $\cdot$ Mental health $\cdot$ Evidence $\cdot$ RCT . Pharmaceuticalization emilia.sanabria@cnrs.fr 
This article examines the multiple, contested values of the herbal brew ayahuasca as it travels out of Amazonia, and is taken up in Christian and psychospiritual urban ritual formations around the world or evaluated within clinical trials. Ayahuasca is a psychoactive herbal brew originating in the Upper Amazon region where it is used in shamanic settings (Dobkin de Rios 1984; Labate and Cavnar 2014). It is generally composed of two native Amazonian plants: the Banisteriopsis caapi vine and the leaves of the Psychotria viridis shrub. The brew has many names but is known internationally under the Quechua name "ayahuasca". Ayahuasca has gained unprecedented visibility internationally as it has shown astonishing promise in the treatment of depression (Palhano-Fontes et al. 2019; Sanches et al. 2016) and addiction (Loizaga-Velder and Verres 2014; Thomas et al. 2013; Liester and Prickett 2012; Talin and Sanabria 2017). From a biomedical perspective, ayahuasca functions as a classic psychedelic or hallucinogen and its efficacy, like that of psilocybin (the active ingredient in so-called 'magic' mushrooms), LSD or MDMA is understood as deriving from a common pharmacological serotonergic activation of $5-\mathrm{HT}_{2 \mathrm{~A}}$ receptor agonism (dos Santos et al. 2016; Schindler et al. 2018; Inserra 2018; dos Santos, Bouso, and Hallak 2020).

Given that ayahuasca does not have a clear pharmaceutical market value (yet), this paper deals with the promissory horizon of value it holds among the champi-AQ2 ons of the so-called psychedelic medicine renaissance (Inserra 2018; dos Santos et al. 2020; Jiménez-Garrido et al. 2020; Sessa 2012; Szabo 2015; Carhart-Harris et al. 2014), and with the value it holds among healers I have been working with who use ayahuasca in ritual settings. The value I explore is still in the process of being negotiated, through clinical trials or through debates over the proper use of ayahuasca, its patrimonialization or the recognition of Indigenous value generation and adequate compensation. The trajectory of valuation I am underscoring here overlaps with and eludes classic pharmaceutical processes of valuation of the kinds analysed by anthropologists of the pharmaceutical industry (Petryna et al. 2006; Peterson 2014; Dumit 2012; Sunder Rajan 2005, 2017; Gaudillière and Hess 2013). In this article, I mobilize the notion of the promissory to point to the way the ethical horizon of alleviating global mental health suffering is tightly coupled to capitalized versions of the promissory (Martin et al. 2008; Haase et al. 2015), such as is made evident in venture capitalist investor psychedelic events that advise on the market promises of these medicines as they are made into treatments.

I situate ayahuasca within the complex and contested trajectories of psychedelic medicine and its emergent capitalization, while drawing on ethnographic fieldwork with urban ayahuasca practitioners and ritual participants in Brazil. The materials gathered in this article are part of a broader research project on ayahuasca healing and evaluations of therapeutic efficacy titled "Healing Encounters: reinventing an indigenous medicine in the clinic and beyond". This article homes in on divergent assessments of value that come to be negotiated in the spaces of encounter where a highly disparate set of actors (indigenous experts 
and song oenoiuers, psycmiatrisıs, pnarmacoiogisıs, iranspersonai inerapisıs, anthropologists and ethnobotanists, venture capitalists, ayahuasca Church 'Masters,' psychonauts, wellness industry developers, Silicon Valley cryptochain app developers, lawyers, etc.) come together. While the article is deeply informed by the research conducted in more classic ethnographic field sites (participant observation of healing ceremonies and practices in Amazonia and urban Latin American centres, indigenous and non-indigenous practitioner and patient life histories and interviews, etc.), its focus here is on the way global ayahuasca events bring together stakeholders in large-scale international gatherings under a model of bringing together a plurality of perspectives on ayahuasca's value. To do this, I draw on data collected during the three World Ayahuasca conferences (Ibiza 2014; Rio Branco 2016; Girona 2019¹), during multiple Psychedelic Conferences (such as Breaking Convention in London, Beyond Psychedelics in Prague, the International Conference of Psychedelic Research in Amsterdam, the Multidisciplinary Association for Psychedelic Science in Oakland), as well as during psychedelic webinars and investor or 'cryptodelic' online events. I and members of my team participated as speakers in many of these events, and were members of the Indigenous delegation of the 3rd World Ayahuasca conference where we served as translators for two Huni Kuin Indigenous collaborators. The rationale for approaching such spaces as ethnographic sites in their own right (Boyer 2008; Marcus 2013; Holmes and Marcus 2008; Assis and Rodrigues 2018) is that they afford a unique vantage point into the disputes that are at stake around ayahuasca's valorization on the international stage as such events attempt to build in symmetry between 'stakeholders'.

Building on the insights afforded in these interstitial spaces, I argue that ayahuasca is not fully captured by the value logics of capital (Gaudillière \& Sunder Rajan, this volume) and examine the ways in which its promissory dimensions, global circulation and entry into practices of biomedical evidence-making position it in an ambiguous space. Ayahuasca-currently (and it will be interesting to see how this reads in a decade) - is neither captured by the logics of capital, nor entirely outside it. In this sense, ayahuasca's value is appropriable by capital yet its current value is as not-yet-capital. A central question is whether it will simply be engulfed within the political economy of health configured by what Gaudillière and Sunder Rajan (this issue) identify as a triple processes of capitalization, pharmaceuticalization and globalization or whether advocacy for ayahuasca's therapeutic value can contribute to challenging this capitalization of health.

In what follows, I briefly provide some background on ayahuasca's twentieth and early twenty-first century history to set the scene before focussing three aspects of ayahuasca's contemporary valuation: firstly, the negotiation of its clinical value in ways that recognize the extra-pharmacological value that has been identified as key to understanding the efficacy of psychedelic substances; secondly, the stakes of 


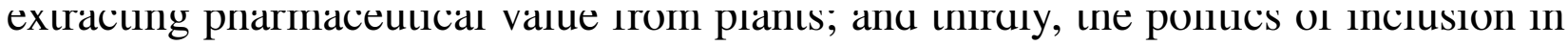
discussions that frame ayahuasca's value globally, bringing together highly divergent world-making practices. I conclude that the circuits of ayahuasca's valorization reveal a complex coproduction (Jasanoff 2004) of value that cuts across and makes strategic use of various scales, sites and situations (in which the internet and international conferences play key roles). Drawing on Fortun's (2001) critique of the stakeholder model of consensus building derived from her analysis of the aftermath of the Bhopal Disaster' management of diversity, the final section returns to the distinction between 'the plural' and 'the multiple' to argue that processes of valuation need to enable conflicting views of the world (or of ayahuasca, as the case may be) to be held and heard.

\section{Value, re-made}

Addressing the psychedelic liberty summit ${ }^{2}$ in May 2020 via Zoom, Indigenous activist and scholar Daiara Tukano of the Tukano Yé'pá Mahsã Nation of the Alto Rio Negro (Brazilian Amazon) gave a powerful presentation on Indigenous concerns with the globalization of ayahuasca. She explained that, for her people, Caapi (the Indigenous term that would enter into the linnean taxonomical nomenclature for the vine Banisteriopsis caapi) is "the fountain of all other knowledge. It is not just a medicine". Daiara Tukano emphasized in deeply moving terms that the life of human and non-human people is intrinsically tied to this sacred plant. Accessing this vital knowledge requires entering into a relationship of apprenticeship with one who guards the knowledge, and undergoing a process of deep transformation through isolation, study, dieta (strict ritual food and behavioural proscriptions). Reminding participants in this international psychedelic gathering that her grandparents and parents had undergone forced placement in boarding schools under the military dictatorship and saw their culture be prohibited, going on to play key leadership roles in the Brazilian Indigenous movement she noted that they saw the fact that, today, there are more white people than Indigenous people drinking ayahuasca as "a very strange thing".

To summarize all too succinctly the complex history that led to this situation, we can point to the fact that in the early twentieth century, along the rubber-tapping frontiers of Peru, Brazil and Colombia, ayahuasca shamanic practices syncretized with Christian and Afro-Brazilian religious practices and ideas, giving rise, in Brazil to several religions each with their specific cult and doctrine and, in Peru, to the tradition of vegetalismo, ritual ayahuasca practices that blend Indigenous and Christian ontologies (Dawson 2013; Labate and MacRae 2010; Taussig 1987; Labate and Cavnar 2014; Fotiou 2018; Bustos 2008). This first moment of ayahuasca's "internationalization" (Labate and Jungaberle 2011) gave way from the 1980s onwards to a boom in "commercially adapted indigenous rituals in ecotourism lodges in the

2FL01 2 Conference program and recordings available at https://chacruna.net/psychedelic-liberty-summit/ 2FL02 (arrecsed Rth Iulv 2030 ) 
Amazon to weekenu worksnops al yoga acauemmes arounu me woriu (sneparu 2017) with ayahuasca irremediably entering into the "global marketplace of New Age spiritualism" with its attendant sanitization of Amazonian shamanism and "bureaucratization of enchantment" (xviii). Weekly ayahuasca rituals now take place in over forty countries including Australia, New Zealand, South Africa, Israel, India, Japan, Russia and twenty-two European countries (Labate and Loures de Assis 2017). These may be led by Indigenous or non-Indigenous Latin American ritual practitioners who travel out of Latin America or by Europeans and North American healers who have received training of various length and seriousness in Latin American ayahuasca traditions or via a spate of dubious commercial training operations. Access to the resource has become a critical issue in many places (Suárez Álvarez 2019), while in others, communities have organized to cultivate the plants. ${ }^{3}$

In the discussions in which I partake there is much debate around the difference between synthetic psychedelic compounds and a plant medicine like ayahuasca, or between traditionally produced ayahuasca (which is harvested from the forest, and prepared by the person who administers it) and the mass produced ayahuasca that is made from cultivated plants, shredded mechanically and cooked on gas stoves, to be shipped out to groups. Often, the ritual preparation of the brew, known in Brazil as feitio, is itself a ritual of core importance during which the congregation comes together to brew with a particular intent or 'energy'. These differentiations highlight divergent forms of valorization. The onus on the end-product (of value) effaces the worlds through which a medicine like ayahuasca works. This capture of ayahuasca by the logic of pharmaceutical value implies the severing of the medicine from its medium (Laplante 2015a, b) or ecology of use, undoing what Mesturini (Mesturini Cappo 2018) calls an "entangled" ayahuasca, that is "a relational space where the power of the plants, of the spirits, and of the ayahuasquera, as well as the influence of colonial invasion, Western thought, foreigners' needs, local resistance, and local collaboration with global issues become inextricable".

Before turning, in the following section, to the construction of pharmaceutical value for ayahuasca, it is useful to briefly examine how healing practices in nonclinical urban spaces construct efficacy and the value logics they sustain. I do so through two sets of examples, which have in common the particularity of being oriented (Ahmed 2006) towards a temporal horizon of amelioration, set in the future. The first concerns the growing popularity of practices of 'microdosing', which involve using sub-perceptible doses of psychedelics (including but not limited to ayahuasca) for therapeutic and self-enhancement purposes. The second concerns discussions among neotraditional ayahuasca circles about what healing is and how it is brought about.

The phenomenon of 'microdosing' with psychedelics has garnered widespread interest globally, as a kind of panacea for depression, anxiety, addiction or to boost creativity, mood and performance. A recent satirical piece published in The Onion 


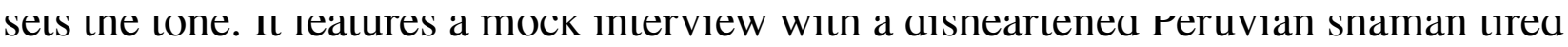
of the constant stream of Silicon Valley executives and Bay Area venture capitalists hoping to gain a deeper insight into their corporate strategies. ${ }^{4}$

Speaking to reporters, the practitioner of ancient South American religious rituals involving the hallucinogenic ayahuasca plant explained that, while he was ordinarily happy to share his culture's spiritual wisdom with others, the constant stream of wealthy Silicon Valley executives seeking transcendental enlightenment had become an increasingly loathsome and disheartening part of his occupation. (Onion 2016).

Accounts of microdosing now circulate widely online, and in business and entrepreneurial press, fuelled by mythic accounts of how Steve Jobs' computing success or Mullis' Nobel prize were the results of insights afforded to them by psychedelics (Doyle 2002). Streams of articles in news magazines have been published exploring "Silicon Valley's Best-Kept Productivity Secret: psychedelics". Here, "creativity" has distinctively neoliberal undertones, rhyming closely with innovation (of the entrepreneurial kind):

Take 'Charlie,' a highly successful entrepreneur. Every month, he ingests MDMA, psilocybin, ayahuasca, or LSD, depending on what he is trying to accomplish. For Charlie, psychedelics work quickly and perform a function crucial for any entrepreneur: getting the mind into what he calls 'a state where it's naturally creative all the time. (Will Yakowicz, Oct 16, 2016 Inc).

A Brazilian plant medicine Instagram account I follow recently began promoting "MicroAya" as "Ayahuasca in homeopathic microdose to clear your vision, lift confusion, relax, combat stress, anxiety, depression, free yourself from fear and help make the right decisions". The ad was shared widely in my WhatsApp groups, with one person commenting "the perfect antidote for Covid related anxiety".

Among the Brazilian urban formations I have been conducted ethnographic research with, the creative value of ayahuasca is seldom couched in such individualized terms as it is in Silicon Valley inflected enhancement logics. The creative potential and value of ayahuasca is usually geared towards building a shared ethos. Growing numbers of urban Brazilians are ritually 'consecrating' ayahuasca in structured ritual ceremonies that take place on a regular basis. A recent estimate held that there are roughly 600,000 users in Brazil who consecrate ayahuasca in a huge array of ritual formations, ranging from groups of twenty or less to over one hundred people (Tofoli 2019). Participants generally maintain strong bonds outside ritual time, at times living together or forming virtual communities in online spaces, such as dedicated WhatsApp groups or private Facebook pages where scientific and press articles on psychedelics, ecology and spirituality widely circulate. Almost all the ritual leaders I interviewed explain that the ceremonies are themselves designed under the influence of ayahuasca. Messages for sessions may be channelled under the effects of the brew. The knowledge or 'message' imparted to ritual participants

4FL01 ${ }^{4} \mathrm{http}: / / w w w . t h e o n i o n . c o m / a r t i c l e / a y a h u a s c a-s h a m a n-d r e a d i n g-a n o t h e r-w e e k-g u i d i n g-t e c-52941$ 4FL02 (arrecsed Gth $\Delta$ nril 2017) 
vy ayanuasca is ilsen mgnly prizeu anu valueu. nere me promlssory anu creallve values attributed to the brew are open-ended and iterative, although they are also somewhat temporally orientated towards a horizon in the future. This was particularly evident in the story recounted to me by Larissa. She has a history of sexual abuse and, when she was fourteen years old, her mother suffered an untimely heart attack and died. Her broken heart became the locus of her pain and she began suffering from panic attack. She learned to quell her terrified heart with alcohol and other sedatives to dissociate. Several years before our encounter, she discovered ayahuasca and began a healing journey with the brew in an ecumenical congregation working with Spiritist and Afro-Brazilian linhas (traditions). She explained that in a recent trabalho (work) she had done a limpeza (cleansing) expunging layer upon layer of her fear. As she cleansed, she understood the nature of this fear and the effect it continued to have over her, beginning as energy but materializing in the body. With support from those holding the ritual space she was able to relax, and, on one occasion, felt "hummingbirds of light" hovering around her heart, "their little beaks weaving, removing, re-doing, cleaning and placing good things" into her heart. When they were finished, she explained, they sealed her heart and flew over to work on the next person. Since this experience she has the conviction that she cured herself of "the future [heart] attack my fear was programming me to have".

A recurrent trope in my interviews with participants and ritual healers is that it is not the ayahuasca that cures. Ayahuasca's value is often presented as 'showing' people the consequences of their actions, communicating information about one's predicament or providing a vision of healing that gets to the source of disease rather than simply addressing symptoms. In this sense-and despite its potent pharmacological action - it is not generally understood to work as a drug (in the magic bullet sense of the word) but rather to facilitate or initiate a process of healing. I am often told that it is this very peculiar and unique modality of healing that is valuable, indeed indispensable, in the present day and age, a framing that often explicitly sets it apart from biomedical or 'Western' health practices.

As ayahuasca is taken up in an ever-growing range of new ritual, recreative or experimental practices questions of authority, authenticity, propriety or safety become ever more acute. How is the contingent, fragile yet potent efficacy of ayahuasca's wildness being enfolded into instituted legal and scientific forms? How is the Other of science made recognizable within its frame and what is at stake for both science and its other in this process (Farquhar and Lai 2014; Laplante 2015a, b)? What neo-ayahuascas will ensue from this process of instituting and reformulating (Gaudilliere 2014; Gaudillière and Pordié 2014)? At stake, is the capacity of ayahuasca's (like other traditional remedies brought into the purview of biomedicine) wildness to survive.

In the following sections, I show that while neotraditional urban practitioners and many psychedelic clinical researchers tend to agree upon the fact that ayahuasca healing cannot be reduced to the substance's action, creating pharmaceutical value is contingent on linking a molecule to a narrowly defined and standardized disease category through clinical trial labour. There is thus an inherent tension as the recognition of this medicine's efficacy requires translation through the apparatus of clinical evidence. The case of avahuasca allows us to interrogate contemnorarv notions of 
value, preciseny vecause il proviues a winuow into a process wnere rauicany unterent co-existing and stratified values encounter each other, on the brink of a possible pharmaceuticalization of ayahuasca.

\section{Extra-pharmacological value}

Psychedelic-assisted clinicians who are attempting to validate these interventions through innovative clinical trials often express how challenging it is to capture the unique efficacy of these interventions with randomized controlled trials. Speaking to a "psychedelic opportunity" investor summit in June 2020, the CEO of a prominent psychedelic start-up unambiguously stated that overcoming this challenge is the only way forward: "The way to scale psychedelic medicines is through the FDA and the FDA values data", he noted. This posits clinical trials as critical technologies of value creation.

Like all drugs, psychedelics need to pass through the different stages of drug regulation prior to authorization. Currently, the most advanced studies are entering Phase3. Based on the highly promising results in Phase2, the FDA granted Breakthrough Therapy Designation to MDMA for the treatment of PTSD in multi-site randomized, double-blind, placebo-controlled, clinical trials. ${ }^{5}$ Organizations involved in the promotion of these trials have developed astute social media strategies to give visibility to early studies and open the barriers to funding for larger clinical trials that can push the evidentiary regimes further up the evidence pyramid. Currently, all such funding is arising from venture capitalist investment. In this peculiar economy, scientific publications take on a promissory function drawing online traction and activating linkages between scientific journals, media sources (given that 'stigma' among the public is seen as a major obstacle), investor news sites and non-profit advocacy organizations. The traffic thus produced can be thought of as modes of producing value (both 'impact', connectivity and 'likeability'); where visibility is of critical strategic value. An example of how this promissory dimension of psychedelic medicine operates is the designation by Inverse magazine of the Beckley Foundation \& Imperial College psychedelic neuroimaging study "Experiment of the Year 2016". This study was selected because it had the potential to "fundamentally alter the future of research into the function of the human brain" (Basu 2016). ${ }^{6}$ Legal firms advising on assets and investor news sites specialized in guiding psychedelic investments mushroomed in 2020. An early projection estimated the magic mushroom industry alone at US\$7 billion by $2027 .^{7}$

${ }^{5}$ Further details available here: https://maps.org/research/mdma/ptsd/phase3 (accessed 8th July 2020).

6 The study is a neuropharmacological experiment into changes in the brain blood flow, electrical activity and network communication patterns of research subjects under the influence of the psychedelic compound LSD. It revealed, experimentally, a series of patterns in subjects' brain structure that account for the therapeutic potential of psychedelic compounds which are understood to trigger hyper-emotional and imaginative states conducive to a "re-setting".

7 Source: https://investingnews.com/daily/life-science-investing/psychedelics-investing/ways-to-inves t-in-psychedelics/ other examples: https://www.fool.com/investing/2020/02/29/forget-cannabis-psych adalin madisina is tha hattar acnv (hoth ameacead Qth Iulv $707 n$ 


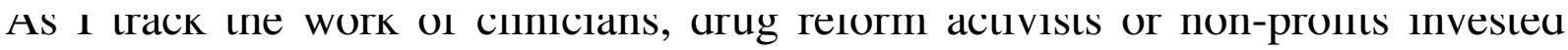
in psychedelic medicine, I note the affect of hope, promise of alleviation of mental health suffering, and a collective denouncing of the inefficacy-if lucrativeness - of hegemonic BigPharma approaches to mental health. There is a critique of magic bullet psychopharmaceutical approaches for depression, addiction and anxiety which are pathologies for which psychedelics are explicitly pitched as alternatives. The therapeutic model at work here is orthogonal to classic psychotropic medication use in psychiatry. Unlike psychiatric meds which are used chronically and unsupervised, psychedelic-assisted therapies involve the intake of only 1-5 doses which are always supervised by a psychiatrist. These 'dosing' sessions are preceded and followed up by psychotherapeutic sessions that enable the material brought up in the dosing session to be 'integrated'. It is the unique combination of the substance and this context-which to some extent mimics the traditional ritual context - which is understood by advocates of this method to be such a powerful modality. This is to say that the effects of psychedelic medicines are dependent on the social dynamics and subjective intentions that play out during the dosing session. Speaking at an international psychedelic event in 2016, Jeff Guss, who is involved in NYU's Psychedelic Therapy Training program, speaks of this approach as being more than simply 'additive,' it involves a co-creation between the medicine, the patient and the therapist; radically reconfiguring the nature of the therapeutic alliance. Psychedelic effects, perhaps more than any other pharmacologically active substance produce highly variable effects, according to the ritual, recreational, experimental, laboratory (or other) contexts in which they are experienced. The rituals accompanying the use of these substances are basic to their effects, and shaped by what many refer to as 'set' (subjective expectations of users) and 'setting' (social and physical environment) of the drug experience (Leary and Metzner 1967). As some ritual leaders have explained to me, there is at times no relation between the dose drank or the potency of a specific batch of the brew and the effects that are experienced. Sometimes the same batch is served on different occasions but the effects are evaluated as having been different. There are multiple reasons for this. The first is that the energy baxada (drawn down) in the salão (collective ritual space) is understood to potencializar (make more potent) the effect of the brew. The collective effect is adduced to individual effects, such that if everyone in the salão is passando mal (having a bad time) or in a particularly elevated mood, these energies are understood to spread among other participants.

The model of health care delivery proposed is diametrically at odds with that of producing surplus health (Dumit 2012). Rather than generating a steady market growth for the drugs by rendering people dependent on their continued consumption for symptom management, psychedelic-assisted therapy purports to heal that is to use the substances for a limited period in view of no longer relying on drugs for wellbeing. Discussions with people invested in this work point to the fact that this 


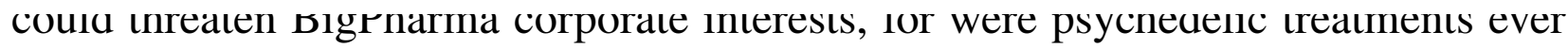
do attain proper validation, the suggestion is that they could take traumatized, anxious, depressed or addicted persons off their chronic psychopharmaceutical regimes. Therein lies a very peculiar aspect of the value of these treatments. It is a value that provides what Kaushik Sunder Rajan (2017) suggests may be "an alternative normative framework to capital". Nevertheless, as Sunder Rajan astutely notes, corporations readily enfold such forms of value in their own value-generating enterprises. They are never, as such "entirely outside the fold of capital but are always appropriable by it. And even as value logics of capital appropriate the ethical, the ethical is often appropriate to capital in that it does not trouble or destabilize it" (Sunder Rajan 2017). Similarly, Gaudillière (2014) notes that value is not an ontological category, "but the outcome of market-oriented processes. Value remains the promise of value and is ultimately of little value if these processes do not end with the making and sale of goods".

In his Keynote address to the Interdisciplinary Conference on Psychedelic Research held in Amsterdam in June 2016, George Goldsmiths, Director of COMPASS, a psychedelic start-up noted "governments can no longer afford the health innovations driven by BigPharma. Meeting the health needs of the twenty-first century requires alternative approaches". In a context of booming mental health problems (such as anxiety, depression, addiction), "psychedelic-assisted therapies show huge potential". Echoing this, just a few months earlier at the Breaking Convention conference on "Psychedelic Consciousness", in London a prominent British psychiatrist expounded the value of (currently illegal) psychedelic compounds for the treatment of some of psychiatry's most intractable problems. "We have incontrovertible evidence that it works, hard facts", he told the audience. "Why can't someone just go down to the Amazon jungle, brew up something that looks, tastes and smells as putrid as Ayahuasca and dish it out in a proper double blind randomized controlled trial?" this psychiatrist lamented. Until then all we will have on this substance is individual case reports. This - in the world of medical policy-making that this psychiatrist operates in - is at the wrong end of the pyramid of evidence in medicine, as far removed from the systematic review of available RCTs that one could be. Just over one year later, I find myself in the Amazonian town of Rio Branco, at the World Ayahuasca Conference listening to Draulio Araujo presenting the preliminary results of what is almost certainly the first double-blind randomized controlled study of ayahuasca: a trial that sought to examine ayahuasca's effect on depression. The study was performed on 70 treatment-resistant patients who had never taken ayahuasca before. The most staggering finding reported was that patients scores on the various scales used to measure depression improved immediately (versus after 15-20 days as with existing treatments). These effects were high in both arms of the trial, revealing a large placebo response (which is generally true in all mental health interventions) but the effects were more durable in time for those in the active arm of the trial (Palhano-Fontes et al. 2019). ${ }^{8}$

${ }_{8 \mathrm{FL} 01}^{8} 33 \%$ of the patients in placebo arm believed they were in the active arm of the trial, two even vomited 


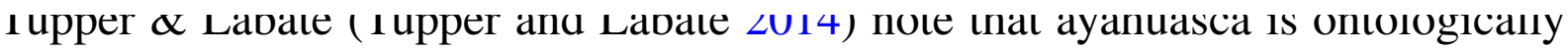
plural. That is, it may be apprehended ontologically as plant teacher, traditional medicine, religious sacrament, material commodity, cognitive tool or illicit drug. In the remainder of this section I want to push this point further by arguing that ayahuasca is multiple not plural (Mol 2002) and that this is the result of it being "informed" as Barry (Barry 2005) has argued after Bensaude-Vincent and Stengers (BensaudeVincent and Stengers 1992). The integration of ayahuasca into the discursive realm of the so-called psychedelic science renaissance is one mode through which ayahuasca is being informed. Barry proposes to read pharmaceutical drugs as informed material, that is as relational. He is concerned with showing how chemistry, as a scientific discipline largely defined by its practical applications, does not just reveal and describe pre-existing molecules 'out there' nor simply impose form on matter. Through its practices, the structure of (chemical) matter becomes richer in information (Barry 2005). Indeed the purified molecule in the lab does not have the same properties as the same molecule in the field or body (Barry 2005:57). The translation that chemistry operates between the properties in the lab and in the field is a process of transferring some elements of one into the other. This is, in many ways, the labour of the clinical trial. What travels with the molecule across these topological ideal spaces is its environment. Thus the material and informational environment of the molecule cannot be thought of as external to the object, Barry notes with Whitehead. This environment becomes constitutive of the molecule itself (2005, pp. 58-59). This, he is careful to note, does not make the molecule "fluid" $(2005$, p. 65) for something endures across the sites (see Peterson 2014, pp. 152-153) for a more explicitly political rendering of this discussion. We can use Barry's insights on the co-constitutive relations between efficacious molecules and their environments, to critically engage with the notion of set and setting dominant in psychedelic science and begin to reflect on the importance of the spaces, temporalities and interpersonal dynamics (between humans and between humans and non-humans) in rendering ayahuasca efficacious.

To conclude this section, I return to the question of value as it pertains to the contexts that are being innovated and developed for psychedelic-assisted therapies. Partaking in online events for investors in this field I was struck to discover that an important area of investment opportunity identified for value generation is referred to as physical and human infrastructure. "A lot of the infrastructure that is going to have to be set up is going to have to be novel and there are fantastic opportunities for IP here", someone who described himself as a "serial entrepreneur" noted in an online event gathering start-up CEOs, clinicians, FDA regulators and lawyers. Imagining the future spaces where psychedelics will be delivered, his co-panellist, a young woman with investments in the cannabis industry noted that "it will have to coexist for a time with existing healthcare structures, but it will outgrow it". Wrapping up the first day of talks, one of the Chairs noted that this industry was no "unicorn" industry and that psychedelic start-ups are "not commodity businesses but 


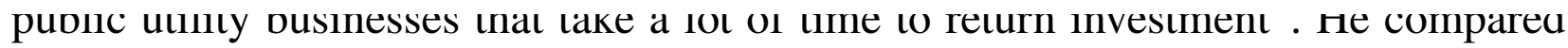
the investment in "infrastructure" for the delivery of these unique substances to Amazon's unparalleled transformation of the sales industry after nearly two decades of not returning any profit. "Your business may begin looking like a pharma company but it will look very different in 10 years", he concluded.

Addressing this event as a Keynote speaker, Goldsmiths-introduced abovespoke to concerns participants raised concerning price by stating.

Bringing a drug to market, typically ... well, the numbers will tell you anything if you torture them long enough. But the hundred, two hundred million that is required to bring a medicine to a large population, I think those numbers are big numbers. But even then, it's not a factor in determining price. It's really about value. And the value you can create for cost avoidance. And I think this is a huge shift that is going on somewhat reluctantly in the pharma industry-let's not talk about price but let's talk about value. Let's be partners in creating value for patients; partners in creating value for health systems. We at Compass are really committed to that.... The research we are starting to do with payers, is-you know-when you look at people who really suffer from treatment-resistant depression, they also have a lot of other things... Often metabolic disease, diabetes, a whole host of things. One can see that things are often related to behaviour and self-care ... so you have the ability for people to take better care of themselves and therefore require less cost to health systems. And when I talked about value before. That's what I mean by value. Can we actually understand deeply the effect this has on people's lives? And to the cost of care? And how they can be not just mentally but physically healthier. Really looking at that comprehensively. That is what we are doing.

This section attempted to map these processes as materializations of an alternative political economy of health (Gaudillière \& Sunder Rajan, this volume). It engages with materials that shed light on how existing health market dynamics are being actively contested and reimagined, as actors of the psychedelic medicine renaissance take on the regulatory frameworks of the FDA and EMA in search of "adaptive pathways for flexible drug delivery innovations", to use emic vocabulary. Given that most of this labour takes place in boardrooms and start-up consultations with lawyers and regulators - far beyond the gaze of the ethnographer-webinars and conference spaces offer a privileged site to study the production of value, or at least its public presentation. In this sense, we can think of these sites as spaces where, alongside the clinical trial, ayahuasca becomes 'informed' in particular ways. What is becoming increasingly clear is that the "psychedelic revival" (Tehseen ref) is overtly challenging corporatized health care and its ineffective chronic drug regimens in ways which are not free from deep rooted commitments to intellectual property and the patent as a form of value generation and protection. 
Unlike reformulated Ayurvedic plant remedies, ayahuasca is not (yet) industrialized, mechanized and standardized, although production modalities have deeply shifted to meet the global demand for the brew, and plants are now being farmed rather than harvested wild and ritual hand pounding being replaced by mechanized shredding. An essential aspect of reformulation in India, Gaudillière (2014) explains is that it severs the phytotherapeutic "product" from the clinical context of individualized treatment:

both from a sociological point of view (preparations are no longer made by doctors but by persons specializing in medicinal plants and their manipulation) and an epistemic point of view (formulations are ready-to-use mixes for specific indications, no longer ad hoc mixes that are part of an individualized treatment regimen) (Gaudillière 2014).

I draw on this to explore two notions of value that are in tension in the case of ayahuasca's valuation. Market value, in the reformulation of Ayurveda case, seems to depend on this rupture or extraction of the 'thing' from its traditional social and epistemic context of use. Value-in Gaudillière analysis-is produced by this operation which puts the product into motion, inserting it into a global circulatory flow from which manufacturers hope to see value produced. This raises a crucial question that commentators on bioprospecting repeatedly return to, namely that while the Convention on Biodiversity's Nagoya treaty extends rights to benefits on profits made from innovations on the natural resources to traditional communities it concomitantly entrenches the patentability of living materials (Foster 2016; Hayden 2003) and "the pharmaceuticalization and inscription into the drug proprietary economy" of traditional herbal medicines (Gaudillière 2014). In the case of ayahuasca, the promissory 'value' is more epistemic than financial. Indeed the promise such a potential therapeutic innovation holds for many of the actors I am encountering seems to be precisely as a kind of heterotopic value or Otherwise (Povinelli 2011) to hegemonic market value. In a sense what is at stake in contestations surrounding the calculative, evaluative or monetary logics that are accompanying ayahuasca's globalization is the potential for the value of ayahuasca's therapeutic potential to remain an alternative while being legally recognized.

Laplante (Julie Laplante 2015a, b) refers to the "preclinical [trial] moment" to home in on this crucial step in the development of plant-based indigenous healing practices into RCT-validated medicines. Ayahuasca could be described as being in both a preclinical and-potentially - a pre-proprietary phase. In the current knowledge economy, the two things are intimately tied together. The process at work with ayahuasca bears both resemblances and divergences from what Gaudillière \& Pordié (Gaudillière and Pordié 2014) have called the "reformulation regime". Reformulation consists in reinventing traditional phytotherapeutics, adapting plant-based healing practices such as those integral to Ayurvedic medicine to 'industrial contexts'. In the context of an innovation pipeline dry-up, 
resormulating traumunal nerval remeutes seems to viler a potential resource ior future pharmaceutical value generation and drug development. Reformulation exploits the properties of mixtures, and brings into question the molecular, chemistry-based and purity-oriented drug-invention model that dominates in Western industrial pharmacy (Gaudillière 2014). However, unlike the cases of Ayurveda or of traditional Chinese or African herbal remedies that anthropologists have studied (Wahlberg 2014; Hsu and Harris 2010; Gaudillière and Pordié 2014; Lai and Farquhar 2015; Laplante 2015a, b; Langwick 2015), ayahuasca is not part of a broader instituted system of traditional herbal-based medical practice nor is the revitalization of this medicine explicitly part of a state effort to standardize indigenous medicines, as important components of nation-building strategies as seems to be the case in the African or Asian cases described by these authors. The case of ayahuasca's legitimation takes a different route.

Drawing on fieldwork alongside the Shuar in Ecuador, Tym (2020) proposes that industrial capitalist knowledge practices pertaining to plants seek out "isolable, transmissible and commercializable components in the genetic and biochemical matter of nature, which then become privileged elements in the knowledge of and value accorded to nature". Building on Hayden's work, he shows how plants are screened for single-molecule active ingredients by bioassay machines which "can only scan the botanical samples for pre-specified chemical substances" (pp), effectively revealing that plants are understood primarily as inputs into a system of knowledge that predefines what can be evaluated and thereby valorized. Further, he shows that the framework of IP law is itself founded on the capacity for the plant to be industrially produced. The targeted active ingredients that are of interest to industry in plant materials are highly variable in concentration - a fact that is exacerbated in the case of ayahuasca by the fact that it is not a plant but a plant brew-rendering plants somewhat illegible to regulators for whom product standardization is absolutely key. This leads Ikechi Mgbeoji (cited by Tym) to describe the patent system as "speaking a monologue directed towards a narrow epistemological and economic elite".

The tensions that surround the international legal status of ayahuasca point to this very tension between its molecular composition and the whole plant (or whole brew, as it were). ${ }^{9}$ Ayahuasca's legal status has been the object of a great deal of uncertainty, given that it contains a naturally occurring form of dimethyltryptamine (DMT) which is currently listed as a Schedule 1 substance in the 1971 Convention on Psychotropic Substances. This Convention, nevertheless, allows parties to make reservations where wild plants traditionally used for ritual or religious purposes are concerned. The International Narcotics Control Board (INCB) has clearly stated that "ayahuasca and similar ethnobotanicals that contain psychoactive alkaloids included in the 1971 Convention are not under international control" (INCB, cited in (De Loenen et al. 2017). However, in many European countries and in the USA, confusion reigns over the difference between the ayahuasca brew which contains naturally

9FL01 ${ }^{9}$ Helle Kaasik has researched the variability of the chemical composition of different religious groups'

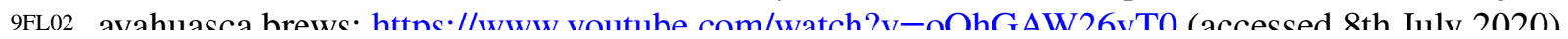




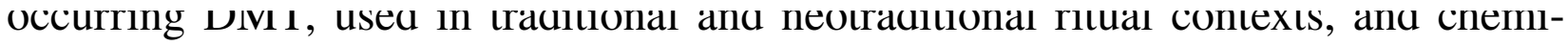
cally extracted and purified DMT that is listed as a Schedule 1 substance.

These approaches to plant value totally overlook Indigenous and traditional understandings of medicinal plants (Craig 2012; Hsu 2012). Hayden (2003, p. 39) draws attention to the fact that medicinal plant resources are always already cultured. They have been reproduced and domesticated for millennia by human collectives who have invested labour and knowledge into their care and propagation. Ethnobotanists of lowland South America have shown that even the wildest frontiers of the Amazon have been managed by human groups for thousands of years, and that the biodiversity that thrives there has been produced, maintained and cultured by human groups (Levis et al. 2017; Rival 2006). Or, as Hayden (ibid) puts it: “"wild” resources ("nature”) are in fact always already-managed ones ("innovation")". This renders the Lockean calculus at the basis of IP totally ill-suited to recognizing the collective (human, and according to my informants more-than-human) labour of producing knowledge, innovating and caring for the potential value to come from the intricate socialities constructed with plant and other non-human allies. How would these forms of recognition function in the intensely prolific global landscape of ritual and therapeutic innovation around ayahuasca? If as I have been arguing ayahuasca is not just the brew but the brew and its context (and the plants and the territories which give them their potency) we need to ask what alternative version of innovation can convey this multispecies entanglement? What proprietary legal regimes are required to account for the proliferation of value production currently underway as ayahuasca ritual forms boom and expand.

While the cultural appropriation of indigenous spirituality (see Tupper 2009) may involve both indigenous and non-indigenous ritual leaders, an important question in this moment of global expansion for ayahuasca is what IP regime or system of economic valuation might come to bear on the brew? Will anyone be able to grow Banisteriopsis caapi and produce, process, prescribe and profit from it? How might the Convention for Biodiversity Nagoya Protocol on access and benefit sharing shape the economics of ayahuasca were it to be further developed within a pharmaceutical regime of value? Who of the myriad traditional, neotraditional and Christian churches would count as 'community' with benefit claiming status? What versions of ayahuasca and its value become authorized in these processes of standardization, legalization and medicalization? A central tension that we have been observing in our work on the HealingEncounters project is between versions of ayahuasca as chemical or plant matter and versions of ayahuasca as a sentient, living being with intelligence. For example, I once asked Ibã Huni Kuin, who is an Indigenous collaborator (and ethical advisor for the project) what ayahuasca would say if it spoke in a human language, for it is understood among the Huni Kuin that ayahuasca "speaks". Smiling, Ibã responds (in Portuguese): "Never forget that animals speak my name. Yube Inu (the name Ibã gives the mythic ancestor who is the spirit of ayahuasca and a central figure in Huni Kuin origin myths), I am here studying your language..." Jokingly he adds, speaking from the perspective of Yube Inu "You know what you can do for me? Plant me. To understand. To take the message. Make a good pure brew and you will receive the message. The message from the spirit of the forest who is guiding us". Movingly, he closed this exchange saying "I want this teaching (of the hrew. of the Yube Inu snirit) to continue for oenerations and oenerations" 
ine uivergence in manmers on envisagning, comprenemung anu valumb ayahuasca - as plant material to be extracted and standardized or cosmological source of all other knowledge_are deep and probably unbridgeable. Such tensions were particularly tangible at the World Ayahuasca Conference to which I now turn.

\section{Contested value}

In the Brazilian context, ayahuasca's legibility to the state is not primarily mediated through Indigenous organizations, as it is in Peru or Colombia. In Brazil, the Ayahuasca churches (Santo Daime and União do Vegetal in particular) have secured legal exemption for ayahuasca on religious grounds and often liaise with clinical laboratories, supplying the brew that is used in experimentations, for example.

In what follows, I explore some of the tensions that this gave rise to in discussions concerning the configuration of the second World Ayahuasca conference, which was held in the ex-rubber-tapping capital Rio Branco, in the Amazonian state of Acre, Brazil. Over one very dense week in October 2016, the conference brought to life in this consequential locality stakes around the global process of ayahuasca's valuation that endure and evolve between conferences through legal decisions, everyday ritual practices, scientific publications and their associated citation practices and through the meticulous labour of international organization active in policy spheres and social media realms to inflect the legal regimes and shape public opinion and knowledge around ayahuasca. I draw on this event to map a series of concerns around ayahuasca's valuation that crystalized in the conference spacetime while spanning well beyond its immediate horizon. My participation and observations of the discussions - both formally structured on the various stages of the event, as a speaker, and around breakfast or diner tables, during visits to historic local ayahuasca centres, etc.-were informed by my ethnographic investments in these questions further afield.

The first panel of the Rio Branco World Ayahuasca Conference was held in the main auditorium and was devoted to Indigenous perspectives. However, what might have been seen as a bold move on behalf of the conference organizers-to follow the Inaugural session with presentations by the Governor of the State of Acre and the Rector of the University by a panel of Indigenous representatives-was excoriated by the panellists. One after the other, the indigenous representatives took the stage, at a table exquisitely ornamented with lush tropical flowers, to question what they denounced as an absurd request: to give their perspective on ayahuasca in ten minutes. The conference celebrated the diversity of perspectives on ayahuasca and as such sought to be inclusive of a plurality of approaches. As such, the streams were organized in "indigenous" "scientific" "policy" and "social sciences and psychology". Such a setup presumes a whole made up of a plurality of perspectives (Strathern 2005). The conference format arises as a space created to bring together a plurality of modes of valuing. Yet what happened directly challenged this. One after the other, each of the indigenous representatives spoke, beginning with a detailed presentation of who they were-in relation to the land and the Elders and the spirits thev worked with Riraci a Yawanawa chief tonk the stage to exnress that in his 
cuiture people speak untı me enu, untı mey mave salu wilal neeus to ve salu. ine sentiment was that it was inappropriate, and indeed offensive, for European enthusiasts of the kind that visit Indigenous communities as ayahuasca tourists to take on the role of hosting — on occupied Indigenous land — and allocating speaking time in a way that felt to the Indigenous participants invited that their presence was merely decorative. Another spoke against the word ayahuasca, "this word is not ours. In our languages of the Acre region it is called many things: Nixi Pãe, Huni Pãe, Uni Pãe, Shuri, but not ayahuasca". The next speaker directly evoked the tensions around the patrimionalization process underway for ayahuasca in Brazil, mainly led by the leaders of the ayahuasca religions, a process several of the indigenous people I spoke with felt excluded from. He declared: "We have been here for centuries caring for this medicine, long before the state became interested in its patrimonialization, or the White man became interested in profiting from it". Yet another speaker took the microphone to address the auditorium in his indigenous language for the entire ten minutes, making the limits of the albeit sophisticated simultaneous translation dispositif (into English, Spanish and Portuguese) painfully obvious. The discomfort, bordering on irritation, was growing in the auditorium and almost palpable. In the row in front of me, two Brazilian scholars who specialize in the study of ayahuasca religions were getting impatient and commenting to each other: "why don't they just stop wasting time and get on with what they have to say?" One asked the other. "They have already been given the main auditorium for the whole morning", the other responded with a raised eyebrow I read as signifying "what more could they want"? Ashinanka leader and Pajé (shaman) Benki was more explicit in situating his response in decolonial terms. He began by reminding the auditorium that the Catholic Church had long demonized and violently repressed ayahuasca shamanic practice, a not so subtle message to the representatives of the Ayahuasca churches who were given an equivalent space the next day in the same room. "When we drink ayahuasca we commune with our antepassados (ancestors) and they remind us that they were killed by the Brazilians [in reference to non-indigenous people]. Ayahuasca does not show you Mary or Jesus but the jiboia (the anaconda, a name commonly given to ayahuasca)" he proclaimed in unambiguously polemical terms. The final panellist, Afonsinho Manduca Mateus concluded:

It is time for there to be another mode of organising this discussion that begins with the recognition of this past. This plenary session is only the beginning; it is not enough. We are still here fighting for our livelihood, for our territories. For this reason we need a completely different mode of organising this discussion. But now we have run out of time and it is time for lunch; for those who have food. The rest will remain hungry. ${ }^{10}$

10 These are translations from my hand written notes, not exact transcripts as recording in this vast audi10FL02 torium was near impossible. 
Anu will thal the panes canle to a very powerius enu.

As one of the members of the organizing committee told me in an informal discussion, the accusations were difficult to hear given that the conference had been held in Acre, at the Brazilian, Peruvian and Colombian border specifically to enable a large number of stakeholders and 'guardians' of ayahuasca, indigenous and religious to participate. With respect to the Ibiza event which preceded it, and had comparatively few indigenous representatives, the Rio Branco event was a substantial step forward in including a plurality of perspectives. ${ }^{11}$ So what are we to make of these tensions? How are we to read the refusal by so many of the indigenous representatives to engage in the terms laid out by the conference format? In the final section, I would like to read this situation through the lens of the difference between the plural and the multiple (Haraway 1991; Strathern 2005; De la Cadena 2015; Mol 2002).

The World Ayahuasca Conference's celebration of diversity places this event within the frame of the plural. As Zhan (2018) notes, the plural is grounded in fragmentation. Within the frame of the plural, the entities that are brought together preexist the relating, as autonomous things, external to each other. Yet as Strathern has forcefully argued, cultures or units are always already "partially connected": more than one and less than many (a point she draws on Haraway to make, and which Mol draws on to develop her notion of a singular multiplicity). Yet, Biraci, Benki and their companions in the struggle of indigenous self-determination make explicitly clear is the way in which their predicament is absolutely not external to that of the settlers and foreigners who organized the conference. The request to begin the conversation on the global valuation of ayahuasca with a recognition of this historical fact is - I would like to argue - a request to move from a world of plurality to a world of multiplicity. It implies recognizing that the current arrangement whereby a plural set of stakeholders (indigenous peoples, scientists, churches) is the product of historical, legal and institutional structures which render them as equivalent, and effaces this history.

In a discussion of Brazil's patrimonialization of ayahuasca, anthropologist and president of the Brazilian Institute of National Heritage Antonio Arantes comments that the peculiarity of the Brazilian scenario is that Ayahuasca's safeguarding is being led by Christian religious groups for religious and not therapeutic processes, whereas in other Latin American countries such as Peru it is associated to indigenous and therapeutic uses (Labate and Goldstein 2009). To Labate and Goldstein's question about how a practice can be recognized as heritage in one way in one country and in another way in the next country, Arantes responds "values attributed to practices are always situational" (62). What transpired from the World Ayahuasca Conference is the way in which (religious) ayahuasca practices are being integrated organizers opened space for an autonomous Indigenous delegation, this had the unwitting effect of positioning Indigenous questions outside the main conference stages. The Indigenous declaration is accessible here: https://www.ayaconference.com/declaration-by-the-indigenous-peoples-and-nations-of-the- 


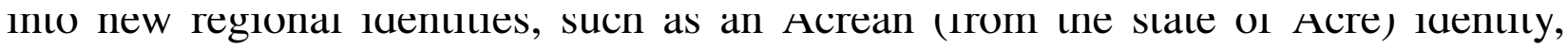
where the second World Ayahuasca conference was held in an attempt to provincialize Euroamerican metropolitanism. The Acrean identity, as it was staked out by Ayahuasca religious groups on one hand and Indigenous groups on the other, is steeped in a deep settler colonial history, the dispossession of Indigenous groups' land, colonized during the rubber boom and for whom the relationship to the colonial Brazilian state continues to be incredibly strained, particularly since the election of Jair Bolsonaro.

What is fascinating in this case is how a locality (such as the state of Acre, Amazonia in Brazil) comes to exemplify a range of things, such as authenticity and the traditional heart of ayahuasca practices, on a global stage (that is, to a community of onlookers who mainly situated in North America and Western Europe) while internally - so to speak - this space is composed of highly stratified and yet partially connected relations that, in this instance, refused the unified inclusive picture that in some regard was expected. This is to say that the value of holding this event in Amazonia under the auspices of this inclusive agenda was highly performative. One of the indigenous representatives I spoke with (who asked to remain anonymous) felt that the organizing committee had little understanding of the local politics of ayahuasca in this region and the historic tensions between the Churches and the indigenous groups, but that this was far from their concerns. The real objective, in his view, was protecting and legitimizing ayahuasca use in Europe and North America. What mattered, so to speak, was less how Indigenous people valued this sacred beverage, and more the recreational and self-enhancement value or potential market value white people were carving out for this ancient medicine.

\section{Conclusion}

Drawing on de la Cadena's $(2015$, p. 33) explicitly political retooling of the concept of "partial connections" in the context of Latin American cosmopolitics, I suggest that the production of a globalized sphere of valuation for ayahuasca-enacted through such psychedelic events, clinical trials, Pubmed publications, social media, drug reform and post-prohibition non-profits, to name but some-needs to attend to the ways in which multiple local values interrupt and reconfigure each other. Failing this, there is a danger that behind the language of inclusion and diversity further appropriations and dispossessions continue to take place.

My discussion of the World Ayahuasca Conference reveals the tensions at work between a politics of the plural and a politics of the multiple. The global story I am narrating here is not one of biomedical expansion from centre to periphery nor is this simply a case of legitimating in an international context a local, indigenous herbal remedy. Thinking the question of value alongside the question of the global involves tracking the shifting ways in which value is constituted in relation to the local or the global and examining how the registers of the local or the global function differentially at different moments. What becomes clear in this context is the way in which locality and universality function as guarantors of values in a context of multinle and shifting comnetino arenas for the realization of values. And here 
we canl see now, m particurar wnere me Ayanuasca conterences are concernea-me choice of locality from which the idealized production of a sense of 'global' (as in the 'World' Ayahuasca) is anything but neutral.

Tracing the fragile, looping trails of co-constituted authority that link ancestral indigenous plant knowledge to those made incandescent under the fMRI scan is a veritable challenge. It raises critical questions for Theory itself, as Zhan (2018) notes. Interrogating STS's fixation on power and materiality, Zhan asks whether the discipline has ended up "reproducing what we set out to critique by leaving little room for spirits, wonders, gods, the cosmic, and the ineffable?" Drawing on her analysis of classical Chinese medicine entrepreneurs strategies to distinguish themselves from scientized Traditional Chinese Medicine practice, Zhan shows that Weber rested his analysis of the spirit of capitalism on an otherworldly/this-worldly divide predicated on sweeping generalizations about Chinese 'religion,'

the worlding of such theories-or rather, Theory itself-entails the violent unworlding of other ways of thinking, doing, and being which renders them unimaginable, unthinkable, and undoable. The challenge we face, as I see it, is not having to come up with a better or bigger theory, but rather taking the politics of imagination seriously and coming up with - and staying with-alternative accounts of worlds-in-making.

The first two sections of this article sought to reveal some of the frictions between different ayahuasca world-making projects (those of the laboratory, and those of the urban practitioners, for example) as the otherworldly/this-worldly divide is widened by the apparatus of the clinical trial which removes spirits and the ineffable from explanatory frameworks.

The argument presented here sought to engage with the multiple facets of the promissory horizon that ayahuasca holds for different groups staking out claims about its of value. I have mapped out tensions between fitting ayahuasca into existent modes of (pharmaceutical) valuation on the one hand, and calls to take seriously the 'politics of imagination' at stake in keeping alternative modes of world-making and valuation alive, on the other. Building on an analysis of ayahuasca's partial incorporation into the psychedelic revival (Steinhardt and Noorani 2020) I have proposed to think of ayahuasca as not-yet-capital; that is as both appropriable by and still partially outside biocapital. This raises questions concerning the conditions of possibility for the persistence of alternative worlds (the Otherwise), for their endurance and survival within curtailing social winds (Povinelli 2011, p. 10). In Economies of Abandonment, Povinelli explores the grammatical figurations of late liberalism as they in/capacitate alternative social imaginaries that contest the normative world. Her insights are important to the question of ayahuasca's value in that she shows how late liberalism aggregates social worlds grammatically "through figurations of tense" (past present and future). In the case of ayahuasca's promissory future, there are at least two ways in which figurations of tense are operating. The first is through a logic of hyperbolic promissory narratives of medical progress and access to better mental health treatments, where a regime of drugs for life (Dumit 2016) such as methadone substitution or long-term antidepressant use is framed as lucrative but not healthy The second is throlloh strateoic forms of annonriation of tradition and 


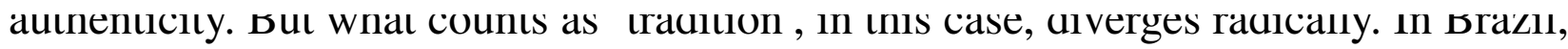
as we have seen, ayahuasca has come to exist as 'tradition' in two radically different subjective formations: as a shamanic, Indigenous practice associated with what Povinelli refers to as genealogical society (indigeneity as defined by a continuity in blood, kinship and culture) and as a Christian religious sacrament upheld by the 'autological subject' of the Ayahuasca Churches who make legal claims based on a constitutional right to religious exemption that is organized around a very different neoliberal governance.

Returning to the question of plural and the multiple, then, I would like to suggest that a core aspect of ayahuasca's potency - and thus value-lies in its circulation between ontological registers (biomedical, legal, neotraditional and indigenous). Focussing on the translations operating in and between the various ethnographic sites I have mapped enables us to develop a middle ground from which to observe equivocations (Viveiros de Castro 2004), divergences and exchanges in situations of encounter. The challenge continues to be-as Daiara Tukano and other Indigenous voices powerfully remind us-whether these encounters can transform the Western apparatus of knowledge and valuation in such a way that it can recognize ayahuasca not as an object of study but as the instrument and origin of knowledge itself. That is, returning to Zhan's terms, whether Theory can unworld some of the violence it has perpetuated in rendering other ways of valuing and being in the world unthinkable.

Acknowledgements This research was made possible by generous support from the ERC Starting Grant no. 757589 "HealingEncounters" based at CERMES3 (Université de Paris, EHESS, CNRS). I am grateful to the participants of the Making of Pharmaceutical Value: Drugs, Diseases and the Political Economies of Global Health workshop held in Paris in June 2016, in particular Thomas Cousins, JeanPaul Gaudillière, Kristin Peterson and Kaushik Sunder Rajan. Special thanks to Piera Talin and Clayton França for the discussions that took root in Rio Branco, and to Joseph Dumit for the all the inspiring conversations that have shaped my thinking; as well as to the three anonymous reviewers who provided valuable — no pun intended — feedback on earlier versions of the argument.

\section{Compliance with ethical standards}

Conflict of interest I do not have any competing interests-intellectual or financial-in the research detailed in the manuscript.

Ethical approval I confirm that the manuscript is composed of original material that is not under review elsewhere, and that the study(ies) on which the research is based has been subject to appropriate ethical review.

\section{References}

Ahmed, Sara. 2006. Orientations: Toward a Queer Phenomenology, vol. 12. Durham: Duke University Press.

Assis, Glauber Loures, and Jacqueline Alves Rodrigues. 2018. Uma Bebida, Muitas Visões: Apontamentos Sociológicos Sobre a II Conferência Mundial Da Ayahuasca. Horizontes Antropológicos 24 (51): 135-165. 
Society 22 (1): 51-69.

Basu, Tanya. 2016. The 2016 Experiment of the Year. Inverse Science.

Benjamin, De Loenen, Oscar Pares Franquero, and Constanza Sanchez Avilés. 2017. A Climate for Change: ICEERS and the Challenges of the Globalization of Ayahuasca. In The World Ayahuasca Diaspora: Reinventions and Controversies, ed. Beatriz Caiuby Labate and Clancy Cavnar Alex. Gearin, 224-241. London: Routledge.

Bensaude-Vincent, Bernadette, and Isabelle Stengers. 1992. Histoire de La Chimie. Paris: La Découverte. Boyer, Dominic. 2008. Thinking Through the Anthropology of Experts. Anthropology in Action 15 (2): $38-46$.

Bustos, Susana. 2008. The Healing Power of the Icaros: A Phenomenological Study of Ayahuasca Experiences. San Francisco: California Institute of Integral Studies.

Carhart-Harris, Robin L., Robert Leech, Peter J. Hellyer, et al. 2014. The Entropic Brain: A Theory of Conscious States Informed by Neuroimaging Research with Psychedelic Drugs. Frontiers in Human Neuroscience 8 (February): 20.

Craig, Sienna. 2012. Healing Elements: Efficacy and the Social Ecologies of Tibetan Medicine. Berkeley and London: University of California Press.

Dawson, Andrew. 2013. Santo Daime: A New World Religion. London: Bloomsbury.

de Dobkin Rios, Marlene. 1984. Visionary Vine : Hallucinogenic Healing in the Peruvian Amazon. Long Grove: Waveland Press.

De la Cadena, Marisol. 2015. Earth Beings: Ecologies of Practice Across Andean Worlds. Durham, NC: Duke University Press.

dos Santos, Rafael G., José C. Bouso, and Jaime E. Hallak. 2020. Hallucinogens/Psychedelics Resurrected as New Tools in Psychiatric Therapy. Brazilian Journal of Psychiatry 00 (00): 1-2.

dos Santos, Rafael G., Flávia. L. Osório, José Alexandre, S. Crippa, and Jaime E. C.. Hallak. 2016. Antidepressive and Anxiolytic Effects of Ayahuasca: A Systematic Literature Review of Animal and Human Studies. Revista Brasileira de Psiquiatria 38 (1): 65-72.

Doyle, Richard. 2002. LSDNA: Rhetoric, Consciousness Expansion, and the Emergence of Biotechnology. Philosophy \& Rhetoric 35 (2): 153-174.

Dumit, Joseph. 2012. Drugs for Life: How Pharmaceutical Companies Define Our Health. Durham, NC: Duke University Press.

Farquhar, J., and L. Lai. 2014. Information and Its Practical Other: Crafting Zhuang Nationality Medicine. East Asian Science, Technology and Society 8 (4): 417-437.

Fortun, Kim. 2001. Advocacy After Bhopal: Environmentalism, Disaster, New Global Orders. Chicago: University of Chicago Press.

Foster, Laura. 2016. The Making and Unmaking of Patent Ownership: Technicalities, Materialities, and Subjectivities. POLAR Political and Legal Anthropology Review 39 (1): 127-143.

Fotiou, Evgenia. 2018. Plant Use and Shamanic Dietas in Contemporary Ayahuasca Shamanism in Peru. In Ethnopharmacologic Search for Psychoactive Drugs: 50 Years of Research (1967-2017), ed. D. McKenna, 55-69. Santa Fe: Synergetic Press.

Gaudillière, Jean-Paul., and Volker Hess. 2013. Ways of Regulating Drugs in the 19th and 20th Centuries. London: Palgrave Macmillan.

Gaudillière, Jean-Paul., and Laurent Pordié. 2014. The Reformulation Regime in Drug Discovery: Revisiting Polyherbals and Property Rights in the Ayurvedic Industry. East Asian Science, Technology and Society: An International Journal 8: 57-79.

Gaudilliere, J.-P. 2014. An Indian Path to Biocapital? The Traditional Knowledge Digital Library, Drug Patents, and the Reformulation Regime of Contemporary Ayurveda. East Asian Science, Technology and Society 8 (4): 391-415.

Haase, Rachel, Marsha Michie, and Debra Skinner. 2015. Flexible Positions, Managed Hopes: The Promissory Bioeconomy of a Whole Genome Sequencing Cancer Study. Social Science \& Medicine 130 (1): 146-153.

Haraway, Donna. 1991. Simians, Cyborgs and Women: The Reinvention of Nature. London: Free Association Books.

Hayden, Cori. 2003. When Nature Goes Public: The Making and Unmaking of Bioprospecting in Mexico. Princeton: Princeton University Press.

Holmes, Douglas R., and George E. Marcus. 2008. Collaboration Today and the Re-Imagination of the Classic Scene of Fieldwork Encounter. Collaborative Anthropologies 1: 81-101. 


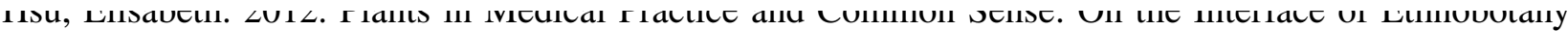
and Medical Anthropology. In Plants, Health and Healing: On the Interface of Ethnobotany and Medical Anthropology, ed. E. Hsu and S. Harris, 1-48. New York: Berghahn Books.

Hsu, Elisabeth, and Stephen Harris. 2010. Plants, Health and Healing: On the Interface of Ethnobotany and Medical Anthropology. New York and Oxford: Berghahn Books.

Inserra, Antonio. 2018. Hypothesis: The Psychedelic Ayahuasca Heals Traumatic Memories via a Sigma 1 Receptor-Mediated Epigenetic-Mnemonic Process. Frontiers in Pharmacology 9 (APR): 1-13.

Jasanoff, Sheila. 2004. States of Knowledge: The Co-Production of Science and the Social Order. London and New York: Routledge.

Jiménez-Garrido, Daniel F., María Gómez-Sousa, Genís Ona, et al. 2020. Effects of Ayahuasca on Mental Health and Quality of Life in Naïve Users: A Longitudinal and Cross-Sectional Study Combination. Scientific Reports 10 (1): 1-12.

Labate, Beatriz, and Clancy Cavnar. 2014. Ayahuasca Shamanism in the Amazon and Beyond. Oxford: Oxford University Press.

Labate, Beatriz, and Ilana Goldstein. 2009. Ayahuasca - From Dangerous Drug to National Heritage: An Interview with Antonio A. Arantes. International Journal of Transpersonal Studies 28: 53-64.

Labate, Beatriz, and Henrik Jungaberle. 2011. The Internationalization of Ayahuasca. Berlin: LIT Verlag.

Labate, Beatriz, and Glauber Loures de Assis. 2017. The Religion of the Forest: Reflections on the International Expansion of a Brazilian Ayahuasca Religion. In The World Ayahuasca Diaspora: Reinventions and Controversies, ed. B.C. Labate, C. Cavnar, and A. Gearin, 57-78. London and New York: Routledge.

Labate, Beatriz, and Edward MacRae. 2010. Ayahuasca, Ritual and Religion in Brazil. London and New York: Routledge.

Lai, Lili, and Judith Farquhar. 2015. Nationality Medicines in China: Institutional Rationality and Healing Charisma. Comparative Studies in Society and History 57 (02): 381-406.

Langwick, Stacey A. 2015. Partial Publics: The Political Promise of Traditional Medicine in Africa. Current Anthropology 56 (4): 493-514.

Laplante, J. 2015. Healing Roots: Anthropology in Life and Medicine. New York: Berghahn.

Laplante, Julie. 2015. Healing Roots: Anthropology in Life and Medicine. New York and Oxford: Berghahn.

Leary, Timothy, and Ralph Metzner. 1967. On Programming Psychedelic Experiences. Psychedelic Review 9: 5-19.

Levis, C., F.R.C. Costa, F. Bongers, et al. 2017. Persistent Effects of Pre-Columbian Plant Domestication on Amazonian Forest Composition. Science 355 (6328): 925-931.

Liester, Mitchell B., and James I. Prickett. 2012. Hypotheses Regarding the Mechanisms of Ayahuasca in the Treatment of Addictions. Journal of Psychoactive Drugs 44 (3): 200-208.

Loizaga-Velder, Anja, and Rolf Verres. 2014. Therapeutic Effects of Ritual Ayahuasca Use in the Treatment of Substance Dependence-Qualitative Results. Journal of Psychoactive Drugs 46 (1): 63-72.

Marcus, George. 2013. Experimental Forms for the Expression of Norms in the Ethnography of the Contemporary. HAU: Journal of Ethnographic Theory. https://doi.org/10.14318/hau3.2.011.

Martin, Paul, Nik Brown, and Andrew Turner. 2008. Capitalizing Hope: The Commercial Development of Umbilical Cord Blood Stem Cell Banking. New Genetics and Society: Critical Studies of Contemporary Biosciences 27 (2): 127-143.

Mesturini Cappo, Silvia. 2018. What Ayahuasca Wants: Notes for the Study and Preservation of an Entangled Ayahuasca. In The Expanding World Ayahuasca Diaspora, ed. Beatriz Labate and Clancy Cavnar, 157-176. London: Routledge.

Mol, Annemarie. 2002. The Body Multiple: Ontology in Medical Practice. Durham, NC: Duke University Press.

Onion. 2016. Ayahuasca Shaman Dreading Another Week Of Guiding Tech CEOs To Spiritual Oneness. The ONION 52: 19.

Palhano-Fontes, Fernanda, Dayanna Barreto, Heloisa Onias, et al. 2019. Rapid Antidepressant Effects of the Psychedelic Ayahuasca in Treatment-Resistant Depression: A Randomized Placebo-Controlled Trial. Psychological Medicine 49 (4): 655-663.

Peterson, Kristin. 2014. Speculative Markets: Drug Circuits and Derivative Life in Nigeria. Durham, NC: Duke University Press.

Petryna, Adriana, Arthur Kleinman, and Andrew Lakoff. 2006. Global Pharmaceuticals: Ethics, Markets, Practices. Durham, NC: Duke University Press. 
Durham, NC: Duke University Press.

Rival, Laura. 2006. Amazonian Historical Ecologies. Journal of the Royal Anthropological Institute 12 (s1): S79-S94.

Sanches, Rafael Faria, Flávia. de Lima, Rafael G. Osório, Dos Santos, et al. 2016. Antidepressant Effects of a Single Dose of Ayahuasca in Patients With Recurrent Depression: A SPECT Study. Journal of Clinical Psychopharmacology 36 (1): 77-81.

Schindler, Emmanuelle, Ryan Wallace, Jordan Sloshower, and Deepak D’Souza. 2018. Neuroendocrine Associations Underlying the Persistent Therapeutic Effects of Classic Serotonergic Psychedelics. Frontiers in Pharmacology 9: 177.

Sessa, Ben. 2012. Shaping the Renaissance of Psychedelic Research. The Lancet 380 (9838): 200-201.

Shepard, Glenn. 2017. Forward. Ayahuasca in the Twenty-First Century: Having It Both Ways. In The World Ayahuasca Diaspora: Reinventions and Controversies, xv-xix. London and New York: Routledge.

Steinhardt, Joanna, and Tehseen Noorani. 2020. The Psychedelic Revival. www.culanth.org. Hot Spots, Fieldsites. https://culanth.org/fieldsights/series/the-psychedelic-revival, accessed October 8, 2020.

Strathern, Marilyn. 2005. Partial Connections. Updated. London: Rowman \& Littlefield.

Suárez Álvarez, Carlos. 2019.. Ayahuasca, Iquitos and Monster Vorax. http://www.ayahuascaiquitos.com/ en/index.php/2019-05-07-19-55-48/book-ii-a-cash-crop.

Sunder Rajan, Kaushik. 2005. Biocapital: The Constitution of Post-Genomic Life. Durham NC: Duke University Press.

Sunder Rajan, Kausik. 2017. Pharmocracy: Trials of Global Biomedicine. Durham, NC: Duke University Press.

Szabo, Attila. 2015. Psychedelics and Immunomodulation: Novel Approaches and Therapeutic Opportunities. Frontiers in Immunology 6: 358.

Talin, Piera, and Emilia Sanabria. 2017. Ayahuasca's Entwined Efficacy: An Ethnographic Study of Ritual Healing from 'Addiction.' International Journal of Drug Policy 44: 23-30.

Taussig, Michael T. 1987. Shamanism, Colonialism, and the Wild Man: A Study in Terror and Healing. Chicago and London: University of Chicago Press.

Thomas, Gerald, N. Philippe Lucas, Rielle Capler, Kenneth W. Tupper, and Gina Martin. 2013. Ayahuasca-Assisted Therapy for Addiction: Results from a Preliminary Observational Study in Canada. Current Drug Abuse Reviews 6 (1): 30-42.

Tofoli, Luis F. 2019. How Many Ayahuasca Drinkers Are There in Brazil? Chacruna, November 8. https ://chacruna.net/how-many-ayahuasca-drinkers-are-there-in-brazil/, accessed October 6, 2020.

Tupper, Kenneth W., and Beatriz C. Labate. 2014. Ayahuasca, Psychedelic Studies and Health Sciences: The Politics of Knowledge and Inquiry into an Amazonian Plant Brew. Current Drug Abuse Reviews 7 (2): 71-80.

Tym, Christian. 2020. Medicine as Microcosm: Pharmaceutical Bioprospecting and the Political Epistemology of Nature in Industrial-Capitalist and Indigenous Amazonian Societies. Environment and Planning E Nature and Space 1 (1): 25-43.

Viveiros de Castro, Eduardo. 2004. Perspectival Anthropology and the Method of Controlled Equivocation. Tipití: Journal of the Society for the Anthropology of Lowland South America 2(1). http://digit alcommons.trinity.edu/tipiti.

Wahlberg, Ayo. 2014. Herbs, Laboratories, and Revolution: On the Making of a National Medicine in Vietnam. East Asian Science, Technology and Society 8 (1): 43-56.

Zhan, Mei. 2018. Cosmographic Experiments: Thinking, Doing, and Being with Classical Chinese Medicine. Humanities Futures Online

Publisher's Note Springer Nature remains neutral with regard to jurisdictional claims in published maps and institutional affiliations.

Emilia Sanabria is an anthropologist based at the Centre for research in Medicine, Science, Health and Society in Paris. She is a full-time researcher at the CNRS, author of Plastic Bodies (Duke University Press in 2016) and Principal Investigator of the ERC project Healing Encounters: reinventing an indigenous medicine in the clinic and beyond. 
Journal: $\quad \mathbf{4 1 2 9 2}$

Article: $\quad \mathbf{2 2 2}$

\section{Author Query Form}

\section{Please ensure you fill out your response to the queries raised below and return this form along with your corrections}

\section{Dear Author}

During the process of typesetting your article, the following queries have arisen. Please check your typeset proof carefully against the queries listed below and mark the necessary changes either directly on the proof/online grid or in the 'Author's response' area provided below

\begin{tabular}{|l|l|l|}
\hline Query & Details Required & $\begin{array}{l}\text { A u th or's } \\
\text { Response }\end{array}$ \\
\hline AQ2 & $\begin{array}{l}\text { "Your manuscript has been copy-edited in keeping } \\
\text { with journal style. Please pay attention to any changes } \\
\text { to the use of double and single quote marks. Double } \\
\text { quote marks (“...') are to be used for direct quotes } \\
\text { (when directly quoting from articles/interviews etc.), } \\
\text { and single quote marks are for scare' quotes. If you } \\
\text { have any concerns, please flag them when editing your } \\
\text { proof" (email from Madhan, dated as on 18th May, } \\
\text { 2017). }\end{array}$ & $\begin{array}{l}\text { References Ibiza (2014), Rio Branco (2016); Girona } \\
\text { (2019) were mentioned in the manuscript; however, } \\
\text { these were not included in the reference list. As a } \\
\text { rule, all mentioned references should be present in the } \\
\text { reference list. Please provide the reference details to be } \\
\text { inserted in the reference list. }\end{array}$ \\
\hline AQQ
\end{tabular}

